\title{
Comparison of Utilization an Absorption and Vapour Compression Chiller in Sub-Tropical Country Building - A Feasibility Study
}

\author{
a,buga Martin Simbolon*, `Yudi Prana Hikmat \\ ${ }^{a}$ RCUK Centre for Sustainable Energy use in Food chains, Brunel University London, Uxbridge, UB8 \\ 3PH, United Kingdom \\ b Department of Refrigeration \& Air Conditioning Engineering, Politeknik Negeri Bandung, Bandung \\ 40559, Indonesia \\ ${ }^{\mathrm{C}}$ Department of Electrical Engineering, Politeknik Negeri Bandung, Bandung 40559, Indonesia
}

Received 15 October 2019; accepted 29January 2020

\begin{abstract}
The present study investigates the feasibility of absorption chiller utilization as part of trigeneration system that possibly applied in sub-tropical country building. Trigeneration is refer to the heat utilization from electric generator (combined heat and power, CHP) to generate absorption chiller in order to produce chilled water for air conditioning system (combined cooling, heat and power, CCHP). Compared to the vapour compression system, absorption chiller that is mainly generated by heat waste, promised benefit economically and environmentally. Overall efficiency of $\mathrm{CCHP}$ can reach $71 \%$ and possibly reducing emission until $146709.07 \mathrm{~kg} \mathrm{CO}$. Economic analysis using the Payback period methodology has shown that the CCHP would produce a return on investment of 2.6 years. Improvements absorption chiller and support from government are expected to lead to increased return on investment and improved viability of the system.
\end{abstract}

\section{KEYWORDS}

Variable speed drives

Motor losses

Generator losses

\section{INTRODUCTION}

Sub-tropical climate (like in London, the UK) that consists of four seasons; summer, autumn, winter and spring, has rarely extremely high or low temperatures. In summers, the temperature is warm with a July average high of $22^{\circ} \mathrm{C}$ and average low of $14^{\circ} \mathrm{C}$; however, it can exceed $25^{\circ} \mathrm{C}$ on several days, and exceed $34^{\circ} \mathrm{C}$ on some days in almost every year. In winters, the temperature is chilly, but rarely below freezing point, which is around $5^{\circ} \mathrm{C}-8^{\circ} \mathrm{C}$. Springs have mild days and cool evenings while autumns are usually mild as well but often unsettled as colder air from the arctic and warmer air from the tropics meet (BBC weather, 2010).

This weather condition brings people to create a controlled climate for working areas as a requirement of comfort zone and this should meet with the satisfaction of human being in order to do the proper activities through the year. The comfortable parameters for human, which can be controlled, include temperature of the air, humidity, velocity of the air and the cleanness or purity of the air (Tassou, 2001). To fulfill the comfort parameter a system which operates within 
the comfortable enquiry is needed. Air conditioning system with control climate can provide a comfortable environment for the needs of the human being, it can control the temperature through supply heating or cooling; control the humidity using humidifying or dehumidifying; control the air movement and the air cleanness by using fan and filtration of supply air.

Control parameter in air conditioning should satisfy with the requirements for a comfortable human environment which relatively different in certain place or application and it will follow the comfort design which has been classified. The classification of comfort design is already provided by several associations whose working areas are related to the refrigeration and air conditioning systems, such as: CIBSE (Chartered Institute of Building Services Engineers) and ASHRAE (American Society of Heating Refrigerating and Air conditioning Engineers).

For example, in office building category:

Internal design condition:

Winter $\quad: 21^{\circ} \mathrm{C}-23^{\circ} \mathrm{C}, 20 \%-30 \%$ Relative Humidity (RH)

Summer $\quad: 23^{\circ} \mathrm{C}-26^{\circ} \mathrm{C}, 40 \%-50 \% \mathrm{RH}$

Air Velocity $: 0.13 \mathrm{~m} / \mathrm{s}$

Selected air conditioning for office building will operate with the setting internal design above and depending on the cooling and heating load of the building.

For cooling in summer, air conditioning will use refrigeration system which functions as chiller to absorb the heat from indoor building and release it into outdoor; and in winter or in cold seasons use heater or boiler to add heat into the building. Refrigeration system used in air conditioning is usually a package of vapour compression chiller which has refrigerant gas or fluid as a media of heat transfer. Refrigerants for the system, including air and water, vary depending on the system application and for particular application there are some criteria (Dossat,1979), such as have a lowboiling point and high latent heat which are founded in chemical substance of halogen gas. Two common halogen gases are Choloro Fluoro Carbon (CFC), i.e R-12 for low temperature and low working pressure, and Hydro Cholro Fluoro Carbon (HCFC), i.e R-22 for high working pressure such as for air.

Environmental issues have now become very important in every human activity in the world. Since the effect of each activity will bring an impact to the environment, such as natural cycles, it should be managed as it will reduce bad results caused by human activities. Ozone depletion, green house effect and carbon dioxide emission are some serious problems in accordance with natural change, known as the climate change. The climate change leads to the increasing global temperature and eco system changing. Related to the climate change, air conditioning system for building application has a role in the natural degradation process. One example is halogens gasses i.e. Chloro Fluoro Carbons (CFCs) which is used as the primary working fluid of the air conditioning system. CFCs do not only deplete the ozone layer but also accumulate with carbon dioxide as green house gasses. Meanwhile, energy driven, such as electricity, is needed by this system to produce cooling or heating, and as the result, the electricity consumption will carry a carbon dioxide emission. 


\section{METHOD}

The air conditioning system that uses halogen gasses as the working fluid, utilizes vapour compression machine as the chiller to produce cooling. Sometimes this machine also functions as the heat pump for heating function. Regarding to the effect of this system, vapour compression chiller may be replaced by another alternative machine, one of them is absorption chiller, to provide cooling. An absorption chiller is a kind of refrigeration system that uses solution refrigerant from two different fluids, namely Water - Lithium Bromide (W- $\mathrm{LiBr}$ ) fluid solution. This solution is used for air conditioning application, and circulated by a pump through generator and absorber to replace the function of a compressor in the vapour compression chiller. Based on the replacement of the air conditioning system, the objective of the dissertation is to give an overview for the feasibility to apply the air conditioning absorption into buildings in sub-tropical countries, based on literature reviews of cost and environmental impact for office building application.

From the literature analyses, there are several refrigerants that are already produced, like $\mathrm{R}$ 134a, R-4O7c and R-410a, as a refrigerant fluid instead of R-22 (HCFC). Meanwhile there is a possibility to replace the existing air conditioning from vapour compression chiller into absorption chiller which uses water and lithium bromide ( $\mathrm{Li}-\mathrm{Br})$ as the refrigerant that has no ODP (Ozone Depletion Potential) number. However, several problems may occur in changing a vapour compression chiller into an absorption chiller, leading to the disadvantages of the system such as coefficient of Performance (COP) of an absorption chiller is much lower than vapour compression. It will make economic justification difficult if there is no heat waste. In addition, a larger dimension for the same cooling capacity, which means, the need of more space.

Further evaluations are needed to reveal the benefit of absorption system which will be related to the economical reasons (cost), technical and environmental issues such as ozone depletion, global warming, phased out of HCFCs or CFCs refrigerant and Carbon dioxide (CO $\neg 2)$ emission foot print. The methods to be adopted in this study include an overview of the vapour compression and absorption chiller system, related to the advantages and disadvantages of both systems and economic analyses of the vapour compression and absorption chiller, related to the cost end energy consumption.

\section{AIR CONDITIONING SYSTEM}

Air conditioning system that will be occupied in a building has to meet with the cooling load or heating load demand to satisfy the comfort climate for the occupant and for the building itself during the working period. To decide the utilization hour, which represents the working period of the cooling (implying when the energy to satisfy the cooling demand is started), the cooling degrees days (CDD) with temperature base $10^{\circ} \mathrm{C}$ can be used. By using the CDD with $10^{\circ} \mathrm{C}$ bases, conceptually defined from the maximum and minimum ambient temperature added with internal heat gain with the room setting temperature of $18^{\circ} \mathrm{C}$, Figure 4.2 will be used to estimate the working hour. 


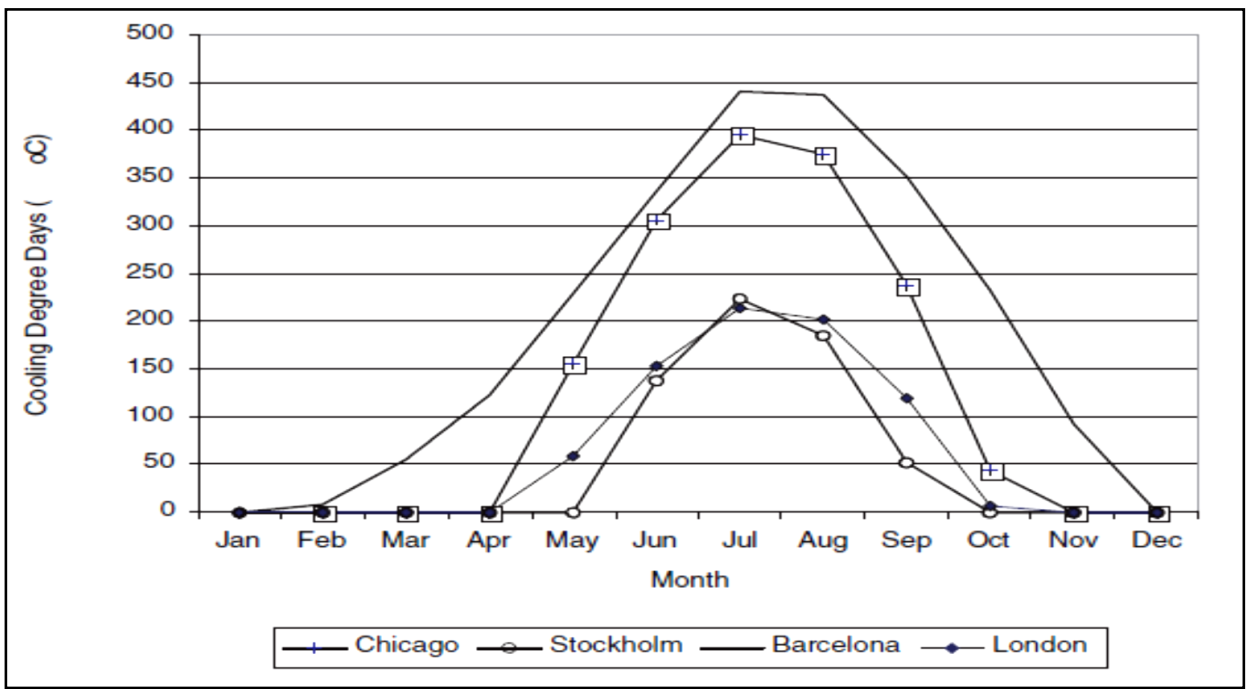

From Figure 1, in London, the working period of cooling system can be estimated from April to October. Furthermore, to estimate the size of the system during the working period, daily aurve load is needed. As seen in Figure 2, the percentage of cooling load estimation hourly reaches the maximum 100\% load around 02:00 pm. However, this estimation can change due to the many factors, and for the 'worst case' scenario, the system must have the ability to overcome the full load of the cooling.

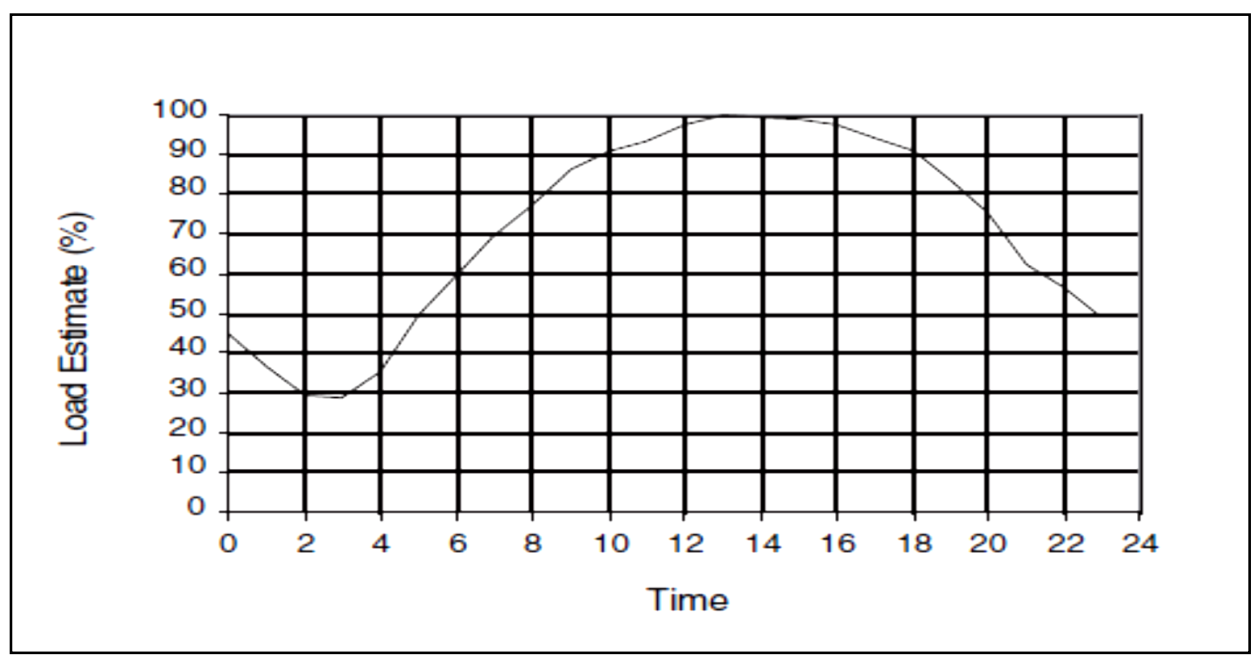

The demand for cooling is needed to size the air conditioning, as well as the total electricity consumption to make an economic feasibility study for the whole system. To analyze the electricity demand, Chartered Institution of Building Services Engineers (CIBSE) makes an electrical load profile for typical office building in one working day. From this graph, which can 
be seen in Figure 3, electricity load starts to increase from 06:00 am and reaches the peak after 09:00 am. The average maximum load will remain until 05:00 pm and then gradually decrease until 09:00 pm. Even though the office hour usually starts at 08:00 am and ends at 05:00 pm (nine working hours), the control system in the building (for the modern building using the Building Management System) has turned the utility system on, (for example the pump, main lighting, air conditioning system and other equipment) two hours before and will turn it off four hours after the working hours. It means, the total working hour for the utilities system is from 06:00 am until 09:00 pm (15 hours) in every working day.

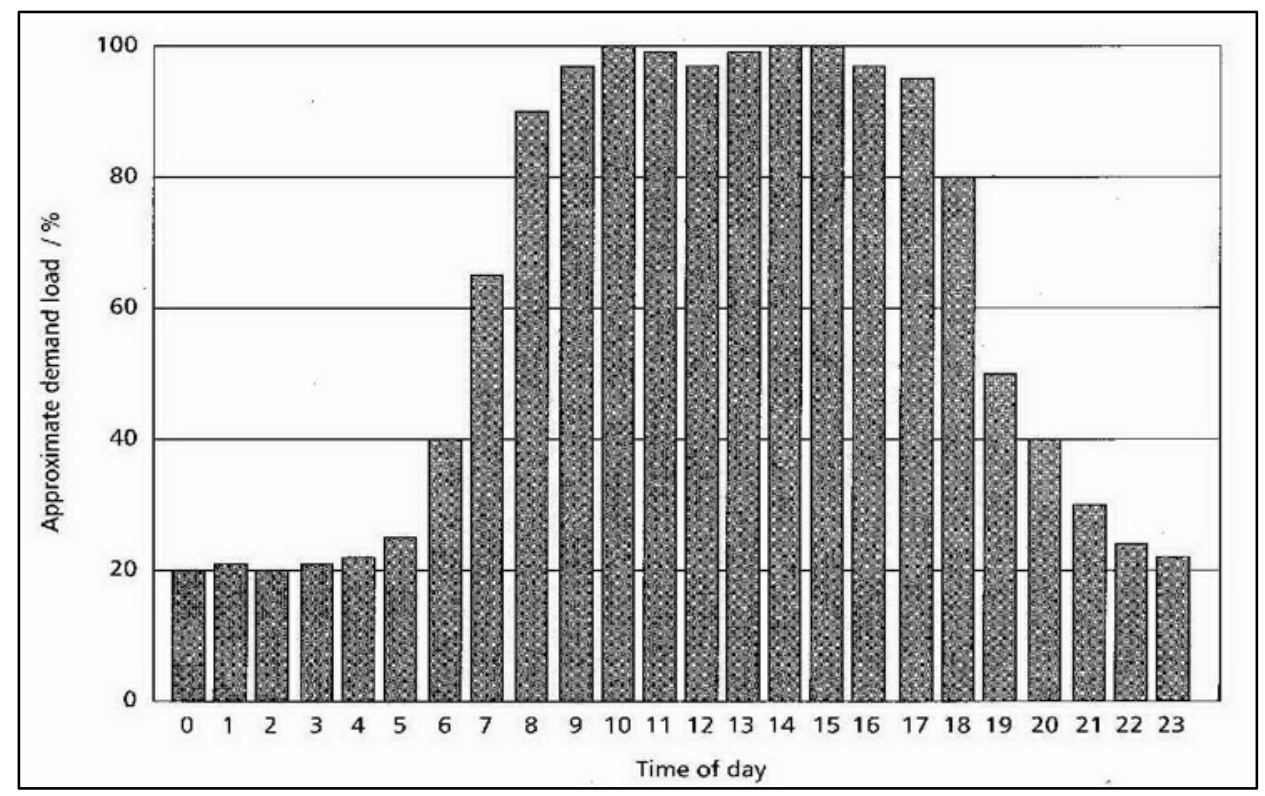

Figure 3. Hourly Electrical Load (source: CIBSE Guide K)

This particular week days load, combined with the cooling load demand, will be used for the plant sizing of the CCHP system, because the plant sizing should be based on the energy demand in the building. Since the CCHP system produces cooling, with an additional absorption chiller, and power in a single process, this system should run as frequent as possible to reach the maximum efficiency. The reason for this is because there is no benefit when the CCHP system stops working. In winter or cold seasons, the CCHP system will be utilized for the space heating to satisfy the heating demand.

Koorolija (2010), in Figure 4, makes a conclusion for the annual building load demand, including equipment, lighting, cooling and heating demand. In the left vertical side is the total annual energy demand per square meter and in the right side is the variation energy demand by the time in one year for each type of the energy demand. During one year, the equipment load in office building is relatively constant while the lighting demand can reduce in summer due to the additional energy from the day lighting. The cooling system, which is much affected by the internal cooling load, will be needed from April to September and heating from October to March. 


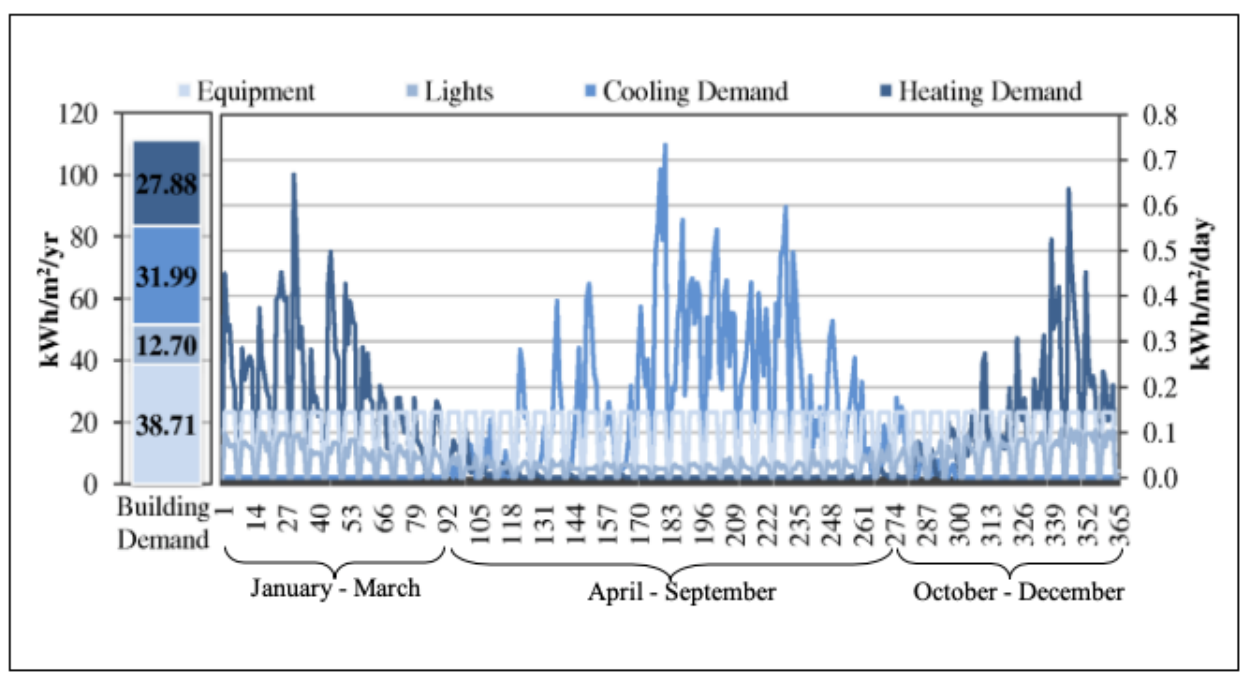

Figure 4. Building Load Profile (source: Korolija, 2010)

For every office building application, the source and the value of internal heat gains are relatively the same. For example, the heat gain from people, lighting and office appliances can be found in the standard data (from CIBSE or ASHRAE). On the other hand, the external heat gains have a significant difference from one particular place to another. They depend on the altitude and latitude which are responsible for the external ambient temperature. Some associations, like CIBSE and ASHRAE, make a classification based on countries and cities. In this project, the cooling peak load and the load profile are limited for office building applications in London, the UK.

\section{CHILLER DATA SPECIFICATION}

To compare the performance of vapour compression chiller and absorption chiller, two types of package chillers from the chiller manufacturer are chosen. The vapour compression chiller uses an air cooled system for the condenser type and shell and tube evaporator for the chilled water. The absorption chiller uses a single effect cooling system and a generator which will be generated by the heat from hot water low pressure. These two systems are chosen based on the application suitable for the office building type.

Those chillers have relatively the same cooling capacity and are manufactured from the same company, Carrier Air Conditioning Company. The product catalogue from the company gives the technical data as follows:

Vapour compression chiller model: 30RB-402 (Carrier Air Conditioning)

Technical Data:

- Nominal cooling capacity $\quad: 262 \mathrm{~kW}$

- $\quad$ Nominal power supply $\quad: 400 \mathrm{~V}, 3 \mathrm{ph}, 5 \mathrm{OHz}$

- Electricity power input $\quad: 129 \mathrm{~kW}$

- Nominal current $\quad$ : 250 A (maximum start-up 535 A) 
The total power input to run this system is based on the electricity power input, $\mathbf{1 2 9} \mathbf{k W}$ and the EER (Energy Efficiency Ratio) is around two.

\section{Absorption chiller model: 16LJ-13 (Carrier Air Conditioning)}

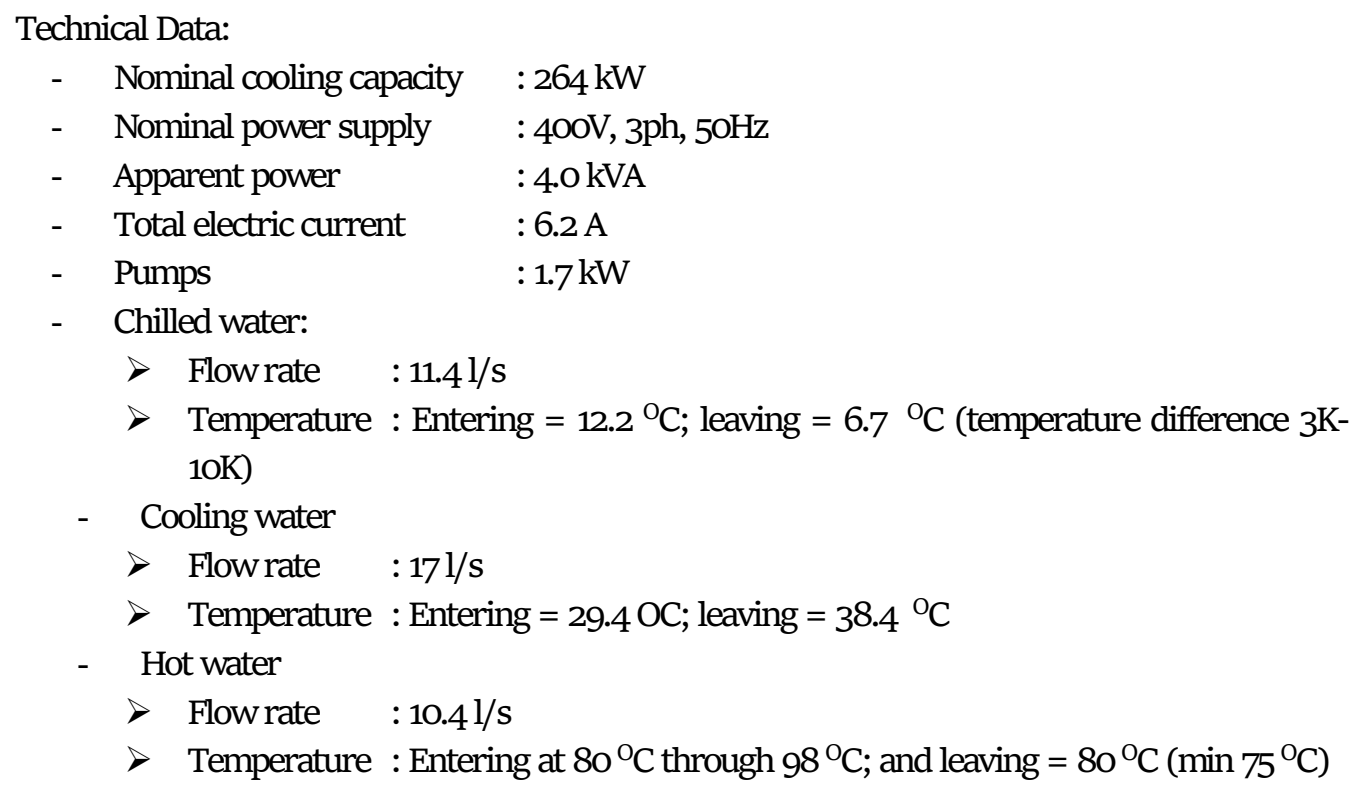

The energy input that will be used to generate the generator comes from the heat which is transferred by the hot water. To calculate this energy input, the property values of water, such as density and heat specific of water, entering and leaving generator will be used.

Water with the temperature of $90 \mathrm{OC}$ (suitable for the CCHP application), the properties are:

- $\rho$, density $=961.62 \mathrm{~kg} / \mathrm{m} 3$

- $\quad \mathrm{cp}$, specific heat $=4.21 \mathrm{~kJ} / \mathrm{kg} . \mathrm{K}$

Then the energy input becomes:

- $\quad$ Hot water input, $Q_{h}=\dot{m} . c p . \Delta T$

$\mathrm{Q}_{\mathrm{h}}=10.4 \times 10^{-3} \times 961.62 \times 4.21 \times(90-80) \approx 421 \mathrm{~kW}$

This energy value can also be used for calculating the COP (Coefficient of Performance) absorption chiller which is divided by the cooling capacity, around o.6. From the energy input, it is also known that higher temperature input will give higher COP.

\section{ENERGY COST AND CO2 EMISSION}

The energy cost and $\mathrm{CO} 2$ emission are factors that can be used to make a comparison between the vapour compression chiller and the absorption chiller. The result of the calculation of the energy cost and $\mathrm{CO} 2$ emission will be analysed in order to make the propose system become feasible. The calculations can be seen in the next part below. 


\section{Energy Cost}

The power input that will be used to run the two chiller types are different. The vapour compression chiller will use only electrical power while absorption chiller will use much more gas rather than electricity. Electricity power from the grid will supply the power for the vapour compression chiller package and also for pumps utilized by the absorption chiller, and then gas boiler will be used to generate heat for absorption chiller.

To calculate the energy cost of both systems, single tariff from the energy supplier is used as the comparison purposes. Tariff of the energy for the comparison is taken from the EDF energy supplier, which is:

Electricity (Standard, London) : $18.03 \mathrm{p} / \mathrm{kWh}$

Gas (single fuel, London) $\quad: \quad 4.24 \mathrm{p} / \mathrm{kWh}$

These tariffs are excluding VAT because a company can claim them back.

The annual working hour for the air conditioning system in offices can be analyzed from the load profile of an office building type. From the load profile in Figure 4.4 and Figure 4.5, the system starts working from 06:00 am to 09:00 pm (15 hours) from April to September. If the working days are from Monday to Friday (5 days) in a week and there are four weeks in one month, then the annual working hour is $15 \times 5 \times 4 \times 6=1800$ hours

The total annual energy consumption and the cost of energy consumption from both vapour compression chiller and absorption chiller are:

- Vapour Compression Chiller

Total annual Electrical power consumption: $1800 \times 129=232200 \mathrm{kWh}$

Total Electricity cost: $232200 \mathrm{kWh} \times 18.03 \mathrm{p} / \mathrm{kWh}=\boldsymbol{\epsilon} \mathbf{4 1 , 8 6 5 . 6 6}$

- Absorption Chiller

Total annual Electrical power consumption: $1800 \times 1.7=3060 \mathrm{kWh}$

CIBSE Guide B gives a reference for the efficiency of a typical conventional boiler (working at low pressure and hot water). At full load it will have efficiency around 75\% (based on Gross Caloric Value), with the assumption of negligible heat loss in the connection pipe. Then the total annual gas consumption becomes: $1800 \times 421 / 0.75=1010400 \mathrm{kWh}$

Total Electricity cost: $3060 \mathrm{kWh} \times 18.03 \mathrm{p} / \mathrm{kWh}=€ 551.72$

Total Gas price: $1010400 \mathrm{kWh} \times 4.24 \mathrm{p} / \mathrm{kWh}=€ 42,840.96$

Total energy cost: $€ 551.72+€ 42,840.96=€ 43,392.68$

\section{$\mathrm{CO} 2$ Emission}

An energy conversion process does not only produce an energy usage but also produce an emission in various formations. For example, gas emission formation, the largest amount of gas emitted that becomes green house gases is Carbon Dioxide gas (CO2). To carry out the amount of Carbon Dioxide emission, a conversion factor is needed to calculate the emission from the use of energy sources. The energy conversion factors, from DEFRA, are quoted as kilogram carbon dioxide equivalent per unit of fuel, for example:

Grid electricity $(\mathrm{kWh}): 0.54 \mathrm{kgCO} 2$ 
Gas (kWh) : $0.184 \mathrm{kgCO} 2$

From the data above, the amounts of $\mathrm{CO} 2$ gas emitted from the cooling process by the vapour compression chiller and absorption chiller are:

- Vapour Compression Chiller

Total Electrical power consumption : $: 232200 \mathrm{kWh}$

Emission of carbon dioxide $\quad: 232200 \times 0.54=125388 \mathrm{~kg} \mathrm{CO} 2$

- Vapour Compression Chiller

Total Electrical power consumption : $3060 \mathrm{kWh}$

Emission of carbon dioxide $\quad: 3060 \times 0.54=1652.4 \mathrm{~kg} \mathrm{CO} 2$

Total gas consumption $\quad: 1010400 \mathrm{kWh}$

Emission of carbon dioxide $\quad: 1010400 \times 0.184=185913.6 \mathrm{~kg} \mathrm{CO} 2$

Total emission of carbon dioxide $\quad: 1652.4+185913.6=187566 \mathrm{~kg} \mathrm{CO} 2$

The calculation of the total energy consumption, energy cost and Carbon Dioxide emission from the vapour compression chiller and absorption chiller shows that the total energy consumption of the absorption chiller is much higher compared to the vapour compression chiller. It occurs because the efficiency of the absorption chiller is much lower than the vapour compression chiller. It explains why the absorption chiller consumes much more fuel energy to produce the same output cooling as the vapour compression.

From the energy cost calculation, it is known that even though the gas price is lower than the electricity price, the absorption chiller consumes the energy more costly than the vapour compression chiller. In terms of the emission, it is also known that the emission of the absorption chiller is higher than the vapour compression chiller, although the conversion factor for the electricity is higher than gas. Since the absorption chiller uses much more heat energy rather than electricity energy, then this system needs a free energy or waste heat energy to make the absorption chiller become feasible in office building application.

\section{ALTERNATIVE ENERGY SOURCE}

The feasibility of the absorption chiller will utilize the heat waste from the electric generator engine that is usually used to supply the electrical power demand in office buildings. The heat waste from the electrical generator will be used to generate the absorption chiller in summer while in winter or cold seasons; it will be used for space heating in building. This utilization is known as CCHP (Combine Cooling Heating and Power). As seen in Figure 5, energy balance of typical CHP unit, the electrical efficiency can reach until 35 percent, and there are two kinds of heat wastes that can be utilized from the system, while the rest become heat losses from flue and casing. 


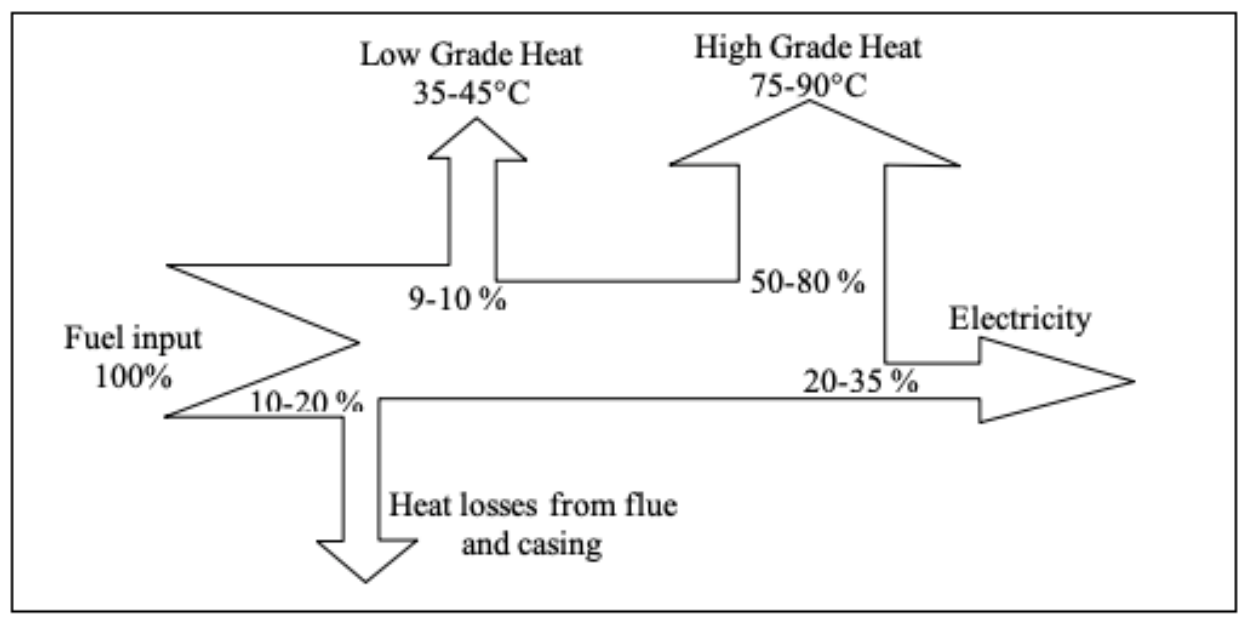

Figure 5. Energy Balance of a Typical CHP Unit (source: Smith, 2007)

Based on the energy balance above, 100 percent fuel input can be converted into electrical power until 35\% and then the heat loss from the flue and casing count until $20 \%$. The rest $45 \%$ of the energy product becomes usable heat waste. This usable heat waste is classified into two categories, low grade and high grade heat, with the temperature of low grade heat which is around 35-45 OC and high grade heat which is around 75-90 OC.

\section{Energy Cost of CCHP System}

When the CHP system will be utilized as the heat generator for an absorption chiller (CCHP system), according to the temperature entering and leaving generator ( $90 \mathrm{OC}-8 \mathrm{OOC}$ ), the usable heat waste that can be used is only the high grade heat. If the maximum $80 \%$ of high grade heat can be taken, neglecting the heat losses from the connection line, then

the amount of heat energy to generate the absorption chiller is:

$421 \mathrm{~kW} / 0.8=526.25 \mathrm{~kW}$

Thus the energy input for the CHP system is:

$526.25 \mathrm{~kW} / 0.45=\mathbf{1 1 6 9 . 4 4} \mathrm{kW}$

With the maximum electricity output which is:

$1169.44 \mathrm{~kW} \times 0.35=409.3 \mathrm{~kW}$

From the calculation above it is known that the efficiency of the system becomes:

$1169.44 /(421+409.3)=0.7099 \approx 71 \%$

Because cooling can be provided when the CHP system is turned on then the absorption chiller and CHP system will run together to satisfy the cooling demand.

It means the working hour of CCHP system for cooling is 1800 hours and the total annual gas consumption is: 
SIMBOLON L. M. ET.AL

1169.44 $\mathrm{kW} \times 1800=2104992 \mathrm{kWh}$ and

Total electric power produced by CCHP is: $409.3 \mathrm{~kW} \times 1800=756740 \mathrm{kWh}$

Using the gas as the fuel then the cost energy of the CCHP system becomes: $2104992 \mathrm{kWh} \times 4.24 \mathrm{p} / \mathrm{kWh}=€ 89,251.66$

If the cost energy to run the electrical pump in an absorption chiller is $€ 551.72$ (from previous calculation) then the total energy cost to run the CCHP system is:

$€ 89,251.66+€ 578.64=€ 89,830.30$

Saving from the CCHP system (cooling and power) compared to the vapour compression chiller is calculated as follows:

Electricity product: $756740 \mathrm{kWh} \times 18.03 \mathrm{p} / \mathrm{kWh}=€ 136,440.22$

Vapour compression chiller: $€ 41,865.66$

Saving (only from energy cost): $(€ 136,440.22+€ 41,865.66)-€ 89,830.30=€ \mathbf{8 8 , 4 7 5 . 5 8}$

\section{$\mathrm{CO} 2$ Emission of CCHP System}

The $\mathrm{CO} 2$ emission of the CCHP system is based on the fuel consumption which is: $2104992 \mathrm{kWh} \times 0.184 \mathrm{kgCO} 2 / \mathrm{kWh}=387318.53 \mathrm{kgCO} 2$

Since the CCHP produces electric power and cooling in the same time, then there is a reduction of $\mathrm{CO} 2$ emission that comes from the product, which is:

From electric power: $756740 \mathrm{kWh} \times 0.54 \mathrm{kgCO} 2 / \mathrm{kWh}=408639.6 \mathrm{kgCO} 2$

From cooling: $125388 \mathrm{kgCO} 2$ (from vapour compression chiller)

Total $\mathrm{CO} 2$ emission of the CCHP system is

$387318.53-(408639.6+125388)=-146709.07 \mathrm{kgCO} 2$

Negative value in the total $\mathrm{CO} 2$ emission system indicates that the CCHP system produces less emission compared to the emission from the vapour compression and even compared to the electricity from the grid. The economic assessment for applying CCHP system is closely related to the energy price that will be used for the main energy source.

\section{PAYBACK PERIOD}

For the economic assessment, a payback period can be used as an indication that the system is feasible for the investment. Simple payback period can be estimated from the total capital cost, running cost (including maintenance cost and fuel consumption cost) and saving from the system. Since the CCHP system is a combination of CHP and absorption chiller then every cost of the CCHP system is calculated from the difference sources. The costs are: 
Capital Cost (Spon's price book):

- Absorption Chiller

- $\quad$ CHP Units (1300 kW fuel input)

- $\quad$ Total $€ 65,353.45+€ 148,151.45$
: $€ 65,353.45$

: $€ 148,151.45$

$=€ 213,504.90$

(These prices are including installation cost)

\section{Maintenance Cost}

- $\quad$ Absorption Chiller (annually $€ 3.53 / \mathrm{kW}$ ) : $€ 3.53$ x $264=£ 931.92$ (source: Syed)

- $\quad$ CHP Units (o.6 p/kWe.h): $0.6 \times 756740=€ 4,540.44$ (source: Carbon trust)

- Total maintenance cost $€ 931.92+€ 4,540.44=€ 5,472.36$

\section{Fuel Cost}

- $\quad$ CCHP system: $€$ 89,830.30

Total running cost: $€ 89,830.30+£ 5,472.36=£ 95,302.66$

\section{Savings}

- $\quad$ Displaced electricity saving: $€ 136,440.22$

- $\quad$ Displaced cooling saving (vapour compression chiller): $€ 41,865.66$

- Total saving: $€ 136,440.22+€ 41,865.66=€ 178,305.88$

Nate Benefit per annum: $€$ 178,305.88 $-€$ 95,302.66 $=€ 83,003.22$

\section{Savings}

\section{Capital cost $/$ Benefit $=€ \mathbf{2 1 3}, \mathbf{5 0 4 . 9 0} / € \mathbf{8 3 , 0 0 3 . 2 2}=\mathbf{2 . 6}$ years}

The 2.6 years payback period above is calculated based on the cooling demand in the building. The CCHP system will reach its maximum efficiency if the system runs in as many hours as possible. One example of the maximum efficiency is by utilizing the heat waste of the CCHP system for heating. The payback period calculation of the CCHP system can become shorter if the total heat waste from the generator is used for space heating during winter or cold season.

The calculation above is based on the simple payback period. It only gives an indication that the CCHP system will give savings during the operation period. When the source of the capital investment is borrowed from a bank then the interest and the inflation rate from the bank should be included into this calculation. In addition, for the further investigation, the present worth analysis can be used to analyse the economic feasibility of the CCHP system.

The UK government policy also makes the CCHP become more attractable. This policy will give CCL exemption in any fuel type consumption for the CHP unit (can be combined with absorption chiller to provide cooling) that has more than $10 \%$ efficiency compared to the conventional system, a system that takes the heat from the boiler and the power from the grid. 
Compared to the conventional system, the efficiency of the CCHP system is $71 \%$ and therefore the CCL exemption is eligible for this system.

\section{CONCLUSION}

The efficiency of the absorption chiller is much lower than the vapour compression chiller which explains why the absorption chiller consumes much more fuel energy and to produce the same output cooling as the vapour compression. From the energy cost calculation, it is known that even though the gas price is lower than the electricity price, the absorption chiller consumes the energy more costly than the vapour compression chiller. Additionally, the emission of the absorption chiller is higher than the vapour compression chiller, although the conversion factor for the electricity is higher than gas.

From the energy cost calculation, even though the gas price is lower than the electricity price, the absorption chiller consumes the energy more costly than the vapour compression chiller. Since the absorption chiller uses much more heat energy rather than electricity energy, then this system needs a free energy or waste heat energy to make the absorption chiller become feasible in office building application.

The calculations of the cost energy above are based on the energy price in London, the UK, where the gas tariff is much lower than the electricity tariff. This condition will give a benefit for the assessment of using CCHP system that consumes gas as the fuel. However, in other countries where different regulations for the energy prices exist, the economic judgement for the energy cost should be analyzed carefully.

\section{REFERENCES}

Action Energy. 2004. Good Practice Guide (GPG 388): Combined Heat and Power for Buildings. Available at: http://files.harc.edu/Sites/GulfCoastCHP/ProjectDevelopment/UKGoodPracticeGuide.pdf [Accessed 7th July 2010]

ASHRAE. 2001. ASHRAE Handbook-Fundamental. Atlanta, USA: American Society of Heating Refrigerating and Air-conditioning Engineers.

BBC. 2010. BBC Weather: Climate Statistic for the UK. Available at: http://www.bbc.co.uk/weather/world/city_guides/results.shtml?tt=tto03790 [Accessed 28 $8^{\text {th }}$ May 2010]

CARBON TRUST. 2010. Carbon Trust: Building Policy. Available at: http://www.carbontrust.co.uk/policy-legislation/Business-PublicSector/Pages/building-regulations.aspx [Accessed 28 ${ }^{\text {th }}$ May 2010]

CIBSE. 2006. CIBSE Guide A: Environmental Design. London, the UK: The Chartered Institute of Building Services Engineers

CIBSE. 2001. CIBSE Guide B: Heating, Ventilation, Air Conditioning and Refrigeration. London, the UK: The Chartered Institute of Building Services Engineers

CIBSE. 2005. CIBSE Guide K: Electricity in Buildings. London, the UK: The Chartered Institute of Building Services Engineers

DECC. 2010. Making DECC Low Carbon: Real-time energy used information. The UK: Department of Energy 
Available at: http://www.decc.gov.uk/en/content/cms/about/low_carbon/low_carbon.aspx [Accessed $7^{\text {th }}$ July 2010]

DECC. 2010. UK energy sector indicators 2010: main indicators dataset. The UK: Department of Energy \& Climate Change. Available at: http://uww.decc.gov.uk/en/content/cms/statistics/publications/indicators/indicators.aspx [Accessed $7^{\text {th }}$ July 2010]

DECC. 2010. Annual Energy Statement: DECC Departmental Memorandum. The UK: Department of Energy \& Climate Change. Available at: http://www.decc.gov.uk/assets/decc/what\%20we\%20do/uk\%20energy\%20supply/237annual-energy-statement-2010.pdf [Accessed $7^{\text {th }}$ July 2010]

DEFRA. 2009. Carbon Trust: Conversion Factor. Available at: http://www.carbontrust.co.uk [Accessed $7^{\text {th }}$ July 2010]

Dossat, R.J., Francis, E. ed. 1997. Principles of Refrigeration. $4^{\text {th }}$ edn. London: Prentice-Hall International

Florides, S. A. et al. 2003. Design and Construction of a LiBr-water Absorption Machine, Energy Conversion and Management, 44 (15) pp. 2483-2508

EDF Energy. 2010. EDF Energy: Electricity Prices. Available at: http://www2.savetodaysavetomorrow.com/documents/OSV7-Ratecard.pdf [Accessed 28 $8^{\text {th }}$ May 2010]

EPA, U.S. 2009. Environmental Protection Agency: Climate Change: Glossary of Climate Change Terms.

Available at: http://www.epa.gov/climatechange/glossary.html [Accessed 28 $8^{\text {th }}$ May 2010]

EPA, U.S. 2010. Environmental Protection Agency: Global Warming Potentials of ODS Substitutes. Available at: http://www.epa.gov/ozone/geninfo/gwps.html [Accessed $28^{\text {th }}$ May 2010]

EPA, U.S. 2010. Environmental Protection Agency: Ozone Layer Protection Gallery. Available at: http://www.epa.gov/ozone/defns.html [Accessed 28 $8^{\text {th }}$ May 2010]

Ge, Y.T. et al. 2009. Performance Evaluation of a Tri-Generation System with Simulation and Experiment, Applied Energy, 86 (11) pp. 2317-2326 Jones, W.P. (2001), Air Conditioning Engineering. $5^{\text {th }}$ edn. Oxford: Butterworth-Heinemann

HM Revenue \& Customs. 2010. Climate Change Levy: Change in Rates. Budget 2010. Available at: http://www.hmrc.gov.uk/budget2010/march/bn55.htm [Accessed $7^{\text {th }}$ July 2010]

IEA. 2002. District Heating and Cooling: Optimization of Cool Thermal Storage and Distribution. International Energy Agency, The Netherland: Novem. Available http://www.ieadhc.org/Annex\%2OVI/annex\%20vi\%20S5\%20cool\%2othermal\%20-3.pdf [Accessed 10 $0^{\text {th }}$ August 2010]

Kilpatrick R., 'Energy Demand Patterns in Non-domestic buildings from empirical data Urban'. Energy Research Group, the UK: Heriot-Watt University. Available at: http://www.pet.hw.ac.uk/ea/seminars/pdfs/111109_RichardKilpatrick.pdf [Accessed $7^{\text {th }}$ July 2010]

Korolija E. et al. 2010. HVAC Systems Energy Demand vs. Building Energy Demand, Proceedings of Conference: IESD PhD Conference: Energy and Sustainable Development: held at: Institute of Energy and Sustainable Development, Queens Building, De Montfort University, Leicester, UK, 21st May 2010 
MacLeay I. 2010. Digest of United Kingdom Energy Statistics 2010. The UK: DECC Available at: www.decc.gov.uk/en/content/cms/statistics/publications/dukes/dukes.aspx [Accessed $7^{\text {th }}$ July 2010]

Mui K.W., Wong L.T. 2006. Cooling load calculations in subtropical climate, Building and Environment, 42 (2007) pp. 2498-2504

Pe' rez-Lombard L. et al. 2007. A Review on Buildings Energy Consumption Information, Energy and Buildings, 40 (2008) pp. 394-398

Smith B.E., Reynolds, Kirby, R. (ed), Reay, D.A. (ed), Zhao, C.Y. (ed). (2007), Energy Conversion Technologies part 2: Combined Heat and Power. Brunel University: Brunel University

Spon's Price Book, Langdon D. (ed), Wall M. G. (ed), (2006), Spon's Mechanical \& Electrical Services Price Book 2006. 37th edn. London: Taylor \& Francis

Syed, A., Maidment, G.G, Missenden, J.F. and Tozer, R.M. 2002. An efficiency comparison of solar cooling schemes, ASHRAE Transactions. Atlanta: American Society of Heating, Refrigerating and Air-conditioning Engineers, 108, pt. 1, pp. 877-886

Tassou, S.A. 2001. Air conditioning part 1. Brunel University: Brunel University

Tassou, S.A. 2005. Energy Conversion Technologies part 1: Refrigeration. Brunel University: Brunel University

UNEP. 2000. The Montreal Protocol on Substances that Deplete the Ozone Layer. United Nations $\begin{array}{llll}\text { Environment } \quad \text { Programme, Nairobi, } & \text { Kenya: UNON }\end{array}$ Available at: http://www.unep.org/ozone [Accessed $7^{\text {th }}$ July 2010] 